Discussion Paper No. 693

\title{
PRICE UNDERTAKINGS, VERS, AND FOREIGN DIRECT INVESTMENT THE CASE OF FOREIGN RIVALRY
}

\author{
Jota Ishikawa \\ and \\ Kaz Miyagiwa
}

\author{
July 2007 \\ The Institute of Social and Economic Research \\ Osaka University \\ 6-1 Mihogaoka, Ibaraki, Osaka 567-0047, Japan
}




\title{
Price undertakings, VERs, and foreign direct investment
}

\section{The case of foreign rivalry"}

\author{
Jota Ishikawa $^{*}$ and Kaz Miyagiwa**
}

\begin{abstract}
Antidumping (AD) petitions are often withdrawn in favor of VERs and price undertakings. We compare foreign firms' incentive to engage in foreign direct investment (FDI) under a VER and a price undertaking, with special emphasis on foreign rivalry. We show that a VER is less likely to induce FDI than a price undertaking or AD. Thus, the importing country can increase the level of protection by replacing an AD duty with a VER. This may account for the GATT ban on VERs, given the proliferation of AD cases during the 1990s.
\end{abstract}

Keywords: FDI, price undertakings, antidumping, VER, WTO

JEL Classification code: F1

Corresponding Author: Kaz Miyagiwa, Institute of Social and Economic Research, Osaka University, Mihogaoka, Ibaraki, Osaka 567-0047, Japan. E-mail: kmiyagiwa@gmail.com

\footnotetext{
\# We are grateful to an anonymous referee and Ig Horstmann, Co-Editor, for their helpful suggestions that led to substantial improvements. We also thank Richard Baldwin, Yongmin Chen, and seminar participants at the University of Colorado, the Graduate Institute of International Studies, and the City University of Hong Kong for their comments. We acknowledge financial support from the Ministry of Education, Culture, Sports, Science and Technology of Japan under the 21st Century Center of Excellence Project. Ishikawa also wishes to thank the Nomura Foundation and the Japan Securities Scholarship Foundation for financial support. We alone are responsible for errors.

${ }^{*}$ Faculty of Economics, Hitotsubashi University, Kunitachi, Tokyo 186-8601, Japan; jota@econ.hit-u.ac.jp

** ISER, Osaka University, Osaka, Japan, and Department of Economics, Emory University, Atlanta, GA, U.S.A.
} 


\section{Introduction}

Over the last-quarter century, use of antidumping (AD) has spread from a handful of users (primarily the United States and the European Union) to more than 70 countries (Prusa, 2001). In reality, however, AD petitioners often withdraw their petitions in favor of direct settlements with exporting firms or governments. For example, during the $1980-85$ period over one-third of U.S. AD petitions were withdrawn in favor of VERs or voluntary export restraints (Prusa, 1992). During the same 1980-1985 period nearly half the AD petitions filed in the EU were settled through price undertakings, which are voluntary price increases offered by foreign firms to offset the injury to domestic producers due to alleged dumping (Messerlin, 1989). More recently, the U.S. and Canada have started to settle $\mathrm{AD}$ cases through price undertakings. ${ }^{1}$

In this paper we examine the relative effect of a price undertaking and a VER on foreign firms' incentive to engage in FDI, with special emphasis on foreign rivalry. There is a well-developed literature on "protection-jumping" FDI, but most of this literature assumes one foreign firm competing with one home firm. ${ }^{2}$ Such a framework cannot reveal any influence foreign rivalry may have on incentives to engage in protection-jumping FDI.

To capture the role of foreign rivalry in firms' choice between exporting and FDI, we consider a model in which two firms from the same foreign country compete with one home firm in the home country. Our analysis offers two main results. A first is that a price

\footnotetext{
${ }^{1}$ Use of VERs was prohibited under the GATT in 1994 (Agreement on Safeguards, Article 11) and the existing VERs have been phased out. In contrast, price undertakings remain in full compliance under GATT and WTO rules (Article 8). See Moore (2005) for more institutional backgrounds.

2 See, e.g., Horstmann and Markusen (1987), Motta (1992), Ishikawa (1998), Blonigen, Tomlin and Wilson. (2004), and Belderbos, Vandenbussche, and Veugelers (2004). Miyagiwa and Ohno (1998) and Blonigen and Ohno (1998) study aspects of foreign rivalry in other contexts.
} 
undertaking leads to more FDI than a VER. To understand this result intuitively, suppose that one foreign firm, under a price undertaking, switches from exporting to FDI while the other exports. Freed from the constraint, the investing firm expands output, depressing the price for the exporter. However, since the export price is not allowed to fall under a price undertaking, the exporter must curtail more exports to keep the price up. Thus, one firm's decision to engage in FDI generates negative externalities on the exporting firm, giving each firm an incentive to invest before the rival does.

With a VER, one firm's choosing FDI over exporting allows the foreign government to reallocate the export quota the firm no longer needs to the exporting firm, thereby relaxing the constraint confronting the latter. Thus, FDI by one firm generates positive externalities on the exporter, thereby diminishing each firm's incentive to invest. This difference establishes our first result.

Our second result concerns importing country welfare. We consider a case in which the home government settles an AD case through a VER or a price undertaking under the political constraint that the home firm should not be made worse off as a result of the settlement. This constraint seems realistic, for otherwise the home firm would never withdraw its $\mathrm{AD}$ petition in favor of such a settlement. In such a setting we show that home country welfare is never lower with a VER - and can be higher - than with a price undertaking. The explanation comes from our first result. Since a VER is less likely to induce FDI, which harms the home firm, than a price undertaking, the home country government faces a less stringent policy constraint under a VER than under a price undertaking. Optimization under a looser constraint gives rise to greater welfare. 
An interesting policy implication is that the home country government can negotiate a more protectionist outcome when it settles AD cases for VERs. Thus, the 1994 GATT decision to prohibit use of VERs can be interpreted as a policy to curb the spread of protectionism.

There is already a large literature on VERs. Price undertakings have been receiving increasing attention from trade economists; see, for example, Vandenbussche and Wauthy (2001) and Pauwels and Springael (2002). Our study is particularly related to that of Belderbos, Vandenbussche, and Veugelers (2004). These authors consider a three-stage game, in which $\mathrm{AD}$ authorities first choose between an $\mathrm{AD}$ duty and a price undertaking, the foreign firm chooses between exporting and FDI, and then the foreign and the home firm compete in prices in the home market. FDI reduces the foreign firm's production cost but may not occur due to high setup cost. In such cases, welfare-maximizing AD authorities choose an $\mathrm{AD}$ duty over a price undertaking to induce FDI, but if concerned with protection of the home firm, they choose a price undertaking to prevent FDI. Thus, there the main focus is on the government's choice between an $\mathrm{AD}$ duty and a price undertaking, with one foreign firm, while here it is on a comparative effect of a price undertaking and a VER in the presence of foreign rivalry.

The differences between a price undertaking and a VER are explored in Moore (2005), although in the absence of FDI. Unlike here he assumes differentiated-goods Bertrand duopoly and shows that a VER leads to a more collusive outcome than a price undertaking.

The reminder of the paper is organized in 6 sections. The next section outlines the model and demonstrates the equivalence among the three policy tools in the absence of FDI. Sections 3, 4, and 5 examine AD, price undertakings, and VERs, respectively. Section 6 discusses policy implications. Section 7 concludes. 


\section{Environment and basic results}

To capture foreign rivalry, the focus of our analysis, we consider a model in which two foreign firms from the same country compete with one home firm in the home market. Additional assumptions simplify the analysis. Firstly, unlike in Belderbos et al. (2004) all firms are symmetric and have zero production costs regardless of the location choices the foreign firms make. Thus, FDI offers no production cost advantages to foreign firms. However, FDI requires a fixed setup cost $\mathrm{k}>0$. Thus, FDI is never chosen over exporting under free trade. Secondly, unlike in Moore (2005) the firms produce homogeneous goods and play a Cournot game. Thirdly, home market demand is linear and written

$$
\mathrm{p}=\mathrm{a}-\left(\mathrm{x}_{1}+\mathrm{x}_{2}+\mathrm{x}_{\mathrm{h}}\right)
$$

where $a>0$ and $x_{h}$ denotes the home firm's output and $x_{1}$ and $x_{2}$ the two foreign firms' outputs.

Cournot competition has an advantage over Bertrand competition in that it establishes the equivalence among $\mathrm{AD}$, the VER and the price undertaking, which makes it possible to isolate the effect of foreign rivalry in policy comparisons. This three-way equivalence is easy to show using Figure 1 in case of only one foreign firm.

$<$ Please place Figure 1 around here. $>$

Letting $x_{h}$ and $x_{f}$ denote the home and the foreign firm's output, respectively, suppose that the Cournot-Nash equilibrium under free trade is indicated by point $\mathrm{N}$, where the home firm's bestresponse function $r_{h}$ intersects that of the foreign firm $r_{f}$ The imposition of AD shifts the 
foreign firm's best-response function to $\mathrm{r}_{\mathrm{ft}}$, and the equilibrium to $\mathrm{N}_{\mathrm{t}}$. Converting this AD duty to a VER set equal to the volume of imports under the $\mathrm{AD}$ duty has no effect on the home firm's best-response function. However, the foreign firm's best-response function consists of the vertical dashed line $\mathrm{AB}$ and the segment of $r_{f}$ above point $A$. The equilibrium remains at $\mathrm{N}_{\mathrm{t}}$, however, proving the equivalence between the two instruments. ${ }^{3}$

Alternatively, convert the $\mathrm{AD}$ case to a price undertaking with the price $\mathrm{p}$ that prevails at $\mathrm{N}_{\mathrm{t}}$. This conversion again has no effect on the home firm's best-response function, but the foreign firm's best-response function now comprises the thick line through $\mathrm{N}_{\mathrm{t}}$, along which the price is constant at $\underline{p}$, and the segment of $r_{f}$ below point $C$. The Nash equilibrium remains at point $\mathrm{N}_{\mathrm{t}}$, however, thereby establishing the equivalence between $\mathrm{AD}$ and a price undertaking. This result extends to the case of two foreign firms as we show in Appendix A. Thus,

Proposition 1: In the absence of FDI, there exist a VER and a price undertaking, which are equivalent to a given $\mathrm{AD}$ duty. ${ }^{4}$

In Figure 1, if the foreign firm were allowed to engage in FDI, it would choose to do so, in which case the equilibrium would be at point $\mathrm{N}$ as under free trade. Therefore, the foreign firm's incentive to engage in FDI must be the same, whether the firm faced a VER or a price

\footnotetext{
${ }^{3}$ Hwang and Mai (1988) were the first to show the equivalence between the tariff and the VER. See also Ishikawa (1994).

${ }^{4}$ With Bertrand competition a VER and a price undertaking are not equivalent, as shown by Moore (2005). Krishna (1989) showed the non-equivalence between a tariff (or an AD duty) and a VER.
} 
undertaking. This conclusion however does not extend when there are more than one foreign firm as we demonstrate in the next three sections.

\section{Antidumping}

We consider a two-stage game, in which two foreign firms simultaneously choose between exporting and FDI, and then play a quantity-setting game with a home firm in the home country. ${ }^{5}$ Since profits depend on the location choice the foreign firms make in the first stage, we first examine all possible second-stage games, and then the foreign firms' FDI decisions.

If both firms export under an $\mathrm{AD}$ duty $\mathrm{t}$, each foreign firm produces $(\mathrm{a}-2 \mathrm{t}) / 4$ and the home firm $(a+2 t) / 4$ units at the price

$$
p(t)=(a+2 t) / 4
$$

The profit to each foreign firm is

$$
\pi(t)=(a-2 t)^{2} / 16
$$

and that to the home firm is

$$
\Pi(t)=(a+2 t)^{2} / 16
$$

If both foreign firms invest, the $\mathrm{AD}$ duty no longer applies, so the equilibrium profits $\operatorname{are~}^{2} / 16$

for the home firm and $\mathrm{a}^{2} / 16-\mathrm{k}$ for the foreign firms as can easily be checked. If only one foreign firm invests, the investor earns $(a+t)^{2} / 16-k$, while the exporter earns $(a-3 t)^{2} / 16$. The

\footnotetext{
${ }^{5}$ Following convention, we ignore what might be going on in the foreign country market. It is straightforward to introduce the segmented foreign market, where the price is higher than in the home market, so as to motivate why there is an $\mathrm{AD}$ duty, to begin with.
} 
following table presents the foreign firms' profits, where I denotes investing, E denotes exporting, and the first entries are the profits to the row player, the convention we retain throughout:

\section{AD Duty (t)}

\begin{tabular}{|c|l|c|}
\hline & \multicolumn{1}{|c|}{ I } & E \\
\hline I & $a^{2} / 16-k, a^{2} / 16-k$ & $(a+t)^{2} / 16-k,(a-3 t)^{2} / 16$ \\
\hline$E$ & $(a-3 t)^{2} / 16,(a+t)^{2} / 16-k$ & $(a-2 t)^{2} / 16,(a-2 t)^{2} / 16$. \\
\hline
\end{tabular}

In the first stage of the game the foreign firms simultaneously choose between I and E, anticipating the profits summarized above. We impose the following conditions on parameter values:

(i) Simultaneous investments are profitable, or $\mathrm{a}^{2} / 16-\mathrm{k}>0$,

(ii) $\mathrm{AD}$ duties are never prohibitive, or $\mathrm{t}<\mathrm{a} / 3$

Figure 2 presents the equilibrium outcomes for relevant values of $k$ and $t$ (see Lemma 1 in Appendix B for details). The figure shows, not surprisingly, that the foreign firms choose FDI over exporting when the cost of investment is relatively low and the AD duty is relatively high.

$<$ Insert Figure 2 around here $>$

\section{Price undertakings}


Suppose that $(\mathrm{E}, \mathrm{E})$ is the equilibrium outcome under AD. Using (1) we can relate the price undertaking to the AD duty by

$$
\underline{p}=(a+2 t) / 4
$$

which, given that $\mathrm{t}<\mathrm{a} / 3$, ranges over the interval $(\mathrm{a} / 4,5 \mathrm{a} / 12)$. It is convenient to consider two cases separately.

Case I: $\mathrm{a} / 4<\underline{\mathrm{p}}<\mathrm{a} / 3$.

This case corresponds to $t \in(0, a / 6)$. If both foreign firms invest, each earns $a^{2} / 16-k$ as in $A D$ cases. If both export, each earns $\pi(\underline{p})=\underline{p}(a-2 \underline{p}) / 2$ (see Appendix A). With only one firm investing, the exporter takes the home firm's and the investor's output, $\mathrm{x}_{\mathrm{i}}$ to choose output $\mathrm{x}_{\mathrm{e}}$ under the constraint that the price not fall below p:

$$
\mathrm{p}=\mathrm{a}-\mathrm{x}_{\mathrm{h}}-\mathrm{x}_{\mathrm{i}}-\mathrm{x}_{\mathrm{e}} \geq \underline{\mathrm{p}}
$$

Calculations show that in the symmetric Nash equilibrium

$$
\mathrm{x}_{\mathrm{e}}=\mathrm{a}-3 \underline{\mathrm{p}}<\underline{\mathrm{p}}=\mathrm{x}_{\mathrm{i}}=\mathrm{x}_{\mathrm{h}}
$$

The investor earns

$$
\pi_{i}(\underline{p})=\underline{p}^{2}-k
$$

while the exporter earns

$$
\pi_{\mathrm{e}}(\underline{\mathrm{p}})=\underline{\mathrm{p}}(\mathrm{a}-3 \underline{\mathrm{p}})
$$

The table below summarizes the profits to the foreign firms in all second-stage games. 
Price undertaking (Case I): $\mathrm{a} / 4<\underline{\mathrm{p}}<\mathrm{a} / 3$

\begin{tabular}{|c|l|c|}
\hline & \multicolumn{1}{|c|}{$\mathrm{I}$} & $\mathrm{E}$ \\
\hline $\mathrm{I}$ & $\mathrm{a}^{2} / 16-\mathrm{k}, \mathrm{a}^{2} / 16-\mathrm{k}$ & $\underline{\underline{p}}^{2}-\mathrm{k},(\mathrm{a}-\mathbf{3} \underline{\mathrm{p}} \underline{\mathrm{p}}$ \\
\hline $\mathrm{E}$ & $(\mathrm{a}-3 \underline{\mathrm{p}}) \underline{\mathrm{p}}, \underline{\underline{p}}^{2}-\mathrm{k}$ & $\underline{\mathrm{p}}(\mathrm{a}-2 \underline{\mathrm{p}}) / 2, \underline{\mathrm{p}}(\mathrm{a}-2 \underline{\mathrm{p}}) / 2$ \\
\hline
\end{tabular}

Case II: $\mathrm{a} / 3<\underline{\mathrm{p}}<5 \mathrm{a} / 12$

This case occurs when an $\mathrm{AD}$ duty was set higher, i.e., $\mathrm{a} / 6<\mathrm{t}<\mathrm{a} / 3$. In this case, $\underline{\mathrm{p}}$ is so high that, when one foreign firm chooses FDI, the equilibrium price falls below $\underline{p}$ even if the other foreign firm has no sale. That is, one firm's decision to engage in FDI forecloses the home market foreclosed to exports. Because of foreclosure there is even a stronger incentive to be a first to invest than in Case I. This yields the following table.

Price undertaking (Case II): $\mathrm{a} / 3<\underline{\mathrm{p}}<5 \mathrm{a} / 12$

\begin{tabular}{|c|l|l|}
\hline & \multicolumn{1}{|c|}{$\mathrm{I}$} & \multicolumn{1}{c|}{} \\
\hline I & $\mathrm{a}^{2} / 16-\mathrm{k}, \mathrm{a}^{2} / 16-\mathrm{k}$ & $\mathrm{a}^{2} / 9-\mathrm{k}, 0$ \\
\hline E & $0, \mathrm{a}^{2} / 9-\mathrm{k}$ & $\underline{\mathrm{p}}(\mathrm{a}-2 \underline{\mathrm{p}}) / 2, \underline{\mathrm{p}}(\mathrm{a}-2 \underline{\mathrm{p}}) / 2$ \\
\hline
\end{tabular}

Figure 3 depicts the equilibrium outcomes for both cases (see Appendix B for details). 
$<$ Insert Figure 3 around here.>

A comparison with Figure 2 shows that for $\mathrm{t} \leq \mathrm{a} / 6$ the equilibrium $(\mathrm{E}, \mathrm{E})$ occurs in a larger set of parameter values. Intuitively, the choice between exporting and FDI depends on two effects. A first is standard; since there are no duties to pay the benefits from FDI are smaller under a price undertaking than under $\mathrm{AD}$. A second is due to foreign rivalry. Under $\mathrm{AD}$ one foreign firm's decision to engage in FDI decreases the equilibrium price, while under a price undertaking the exporting firm must curtail more exports to prevent the price from falling. This externality makes FDI more attractive under the price undertaking. A comparison shows that for $\mathrm{t} \leq \mathrm{a} / 6$ the externality effect is less important.

For $\mathrm{t}>\mathrm{a} / 6$, the externality effect is dominant because of home market foreclosure to exports. Thus, (I, I) is an equilibrium at all relevant parameter values. However, when the cost of investment is sufficiently high $(\mathrm{E}, \mathrm{E})$ can also be an equilibrium because no firm wants to invest if the rival does not, implying multiple equilibria as shown in Figure 3. We summarize the result in

Proposition 2: For $\mathrm{t}<\mathrm{a} / 6$, a price undertaking induces both firms to export in a broader set of parameters than the equivalent $\mathrm{AD}$ duty. For $\mathrm{t}>\mathrm{a} / 6$, a price undertaking can induce more FDI than the equivalent $\mathrm{AD}$ duty.

\section{VERs}

The VER is related to the AD duty by the equivalence formula:

$$
\mathrm{v}=(\mathrm{a}-2 \mathrm{t}) / 2
$$


which ranges over $\mathrm{v} \in(\mathrm{a} / 6, \mathrm{a} / 2)$ given $\mathrm{t}<\mathrm{a} / 3$ (see Appendix A). Under the VER agreement, total exports from the foreign country cannot exceed v; that is, $\mathrm{x}_{1}+\mathrm{x}_{2} \leq \mathrm{v}$. Assume that the foreign government allocates the export quota equally to the two firms when both export. If one firm invests, it no longer needs its export quota so the foreign government can reallocate it to the other firm. As with a price undertaking, consider two cases.

Case $I: v \in(a / 3, a / 2)$.

This case corresponds to $t \in(0, a / 6)$. If both foreign firms export, each firm faces the quota $v / 2$. Given the equivalence, the equilibrium outcome is the same as under the price undertaking. If the two firms invest instead, each foreign firm earns $\mathrm{a}^{2} / 16-\mathrm{k}$. If only one firm invests, the entire quota, $v$, is given the sole exporter. In the present case, since $v>a / 3$ the total quota exceeds the per-firm symmetric Cournot equilibrium output, a/4, implying that the VER is not binding for the exporting firm. With all firms playing a Cournot game unconstrained, the equilibrium profits to the investor and the exporter, respectively, are:

$$
\pi_{\mathrm{i}}=\mathrm{a}^{2} / 16-\mathrm{k} \text {, and } \pi_{\mathrm{e}}=\mathrm{a}^{2} / 16 .
$$

We have obtained the following table.

$$
\text { VER (Case I): } \mathrm{v} \in(\mathrm{a} / 3, \mathrm{a} / 2)
$$

\begin{tabular}{|c|c|c|}
\hline & $\mathrm{I}$ & $\mathrm{E}$ \\
\hline $\mathrm{I}$ & $\mathrm{a}^{2} / 16-\mathrm{k}, \mathrm{a}^{2} / 16-\mathrm{k}$ & $\mathrm{a}^{2} / 16-\mathrm{k}, \mathrm{a}^{2} / 16$ \\
\hline $\mathrm{E}$ & $\mathrm{a}^{2} / 16, \mathrm{a}^{2} / 16-\mathrm{k}$ & $\mathrm{v}(\mathrm{a}-\mathrm{v}) / 2, \mathrm{v}(\mathrm{a}-\mathrm{v}) / 2$ \\
\hline
\end{tabular}


We show in Appendix B that (E, E) is the only equilibrium of this game (see Lemma 4).

Turn next to Case II, in which $\mathrm{v} \in(\mathrm{a} / 6, \mathrm{a} / 3]$. Notice that for $\mathrm{v} \in[\mathrm{a} / 4, \mathrm{a} / 3]$ corresponding to $\mathrm{t} \in[\mathrm{a} / 6, \mathrm{a} / 4]$, the VER is still not binding for the exporter when the other firm chooses FDI. Therefore, $(E, E)$ is the unique equilibrium. For $v \in(a / 6, a / 4)$ corresponding to $\underline{p}$ $\in(3 \mathrm{a} / 8,5 \mathrm{a} / 12)$ or $\mathrm{t} \in(\mathrm{a} / 4, \mathrm{a} / 3)$, however, when one foreign firm invests, the VER becomes binding for the exporter. In equilibrium the exporter produces $\mathrm{v}$ units of output while the home firm and the investing firm produce

$$
x_{h}=x_{i}=(a-v) / 3 .
$$

The exporter earns $\pi_{\mathrm{e}}(\mathrm{v})=\mathrm{v}(\mathrm{a}-\mathrm{v}) / 3$, and the investor makes $\pi_{\mathrm{i}}(\mathrm{v})=(\mathrm{a}-\mathrm{v})^{2} / 9-\mathrm{k}$. Given the range of $\mathrm{v}$, we have $\pi_{\mathrm{i}}(\mathrm{v})>\pi_{\mathrm{e}}(\mathrm{v})$, so there is now an incentive to invest if the other does not (provided that $\mathrm{k}$ is small). The payoffs from all the second-stage games are shown in the table below.

VER (Case II) $\mathrm{v} \in(\mathrm{a} / 6, \mathrm{a} / 4)$

\begin{tabular}{|c|l|c|}
\hline & \multicolumn{1}{|c|}{ I } & E \\
\hline I & $\mathrm{a}^{2} / 16-\mathrm{k}, \mathrm{a}^{2} / 16-\mathrm{k}$ & $(\mathrm{a}-\mathrm{v})^{2} / 9-\mathrm{k}, \mathrm{v}(\mathrm{a}-\mathrm{v}) / 3$ \\
\hline $\mathrm{E}$ & $\mathrm{v}(\mathrm{a}-\mathrm{v}) / 3,(\mathrm{a}-\mathrm{v})^{2} / 9-\mathrm{k}$ & $\mathrm{v}(\mathrm{a}-\mathrm{v}) / 2, \mathrm{v}(\mathrm{a}-\mathrm{v}) / 2$ \\
\hline
\end{tabular}

$<$ Please insert Figure 4 around here $>$

Figure 4 depicts the equilibrium with VERs (see Lemmas 4 and 5 in Appendix B for details). A comparison of figures $2-4$ shows that settling an AD case for a VER leads to less FDI than for a price undertaking. 
Proposition 3. The set of parameter values in which both firms choose exporting over FDI under VERs is a strict superset of those under $\mathrm{AD}$ and price undertakings.

The proposition says that the home country government can, for given $\mathrm{k}$, set a higher level of protection with a VER than with $\mathrm{AD}$ or a price undertaking without triggering FDI, implying that settling an $\mathrm{AD}$ case for a VER can lead to a hidden increase in protection.

\section{Policy implications}

In this section we discuss policy implications of our model. In particular, we consider the following scenario. The home firm petitions for AD protection, but is ready to withdraw the petition if a price undertaking (or VER) agreement can be worked out with the foreign firms or

the foreign government. Suppose that with $\mathrm{AD}$ the equilibrium outcome is (E, E). Now, our question can be stated. Should the home government choose a price undertaking or a VER, if it wants to settle the $\mathrm{AD}$ case under the condition that the home firm is not to be hurt by the settlement? We show that the home country is generally better off with a VER than with a price undertaking.

Suppose that we are in Case I. If the government is constrained to stay within Case I, a price undertaking and a VER yield the same welfare. To see this, observe that $(\mathrm{E}, \mathrm{E})$ is the equilibrium outcome under the equivalent VER whenever it is under AD. Further, in Case I a tighter VER decreases welfare (see Appendix C) while a looser VER harms the home firm. Thus, the government has no choice but to choose the equivalent VER, given the constraint that 
it stays in Case 1. Similarly, when settling an AD case for a price undertaking, the best the government can do is to set the equivalent price target. Thus, the price undertaking and the VER yield the same home country welfare.

Suppose next that the government can choose a protection level beyond the parameter ranges of Case I. By Proposition 3, the set of parameter values resulting in (E, E) under a VER is a strict superset of that under a price undertaking. Operating under a larger constraint set the government can do better with a VER than with a price undertaking. Thus,

Proposition 4. A VER (weakly) welfare-dominates a price undertaking.

\section{Concluding remarks}

In this paper we study the foreign firms' incentives to engage in FDI under a VER and a price undertaking. While there is a well-developed literature on protection-jumping FDI, our approach is novel in that it focuses on foreign rivalry as a determinant of FDI. Our main result is that a price undertaking gives a greater incentive to engage in FDI than a VER. The reason is that with a price undertaking one firm's decision to engage in FDI depresses the export price, forcing the exporting firm to contract exports, whereas with a VER it relaxes the constraint facing the exporting firm as the export quota no longer needed by an investing firm can be reallocated to the exporting firm.

We also explore policy implications of our analysis. Since a VER is less likely to induce FDI than $\mathrm{AD}$ and a price undertaking, the importing country government can negotiate a more protectionist outcome without triggering FDI by settling an $\mathrm{AD}$ case for a VER 
agreement. Thus, our analysis implies that the GATT ban on VERs was a sensible decision to stop the spread of increases in protection.

But if GATT/WTO decisions are nothing but a reflection of member country preferences, one wonders why members agreed to the ban in the first place. To address this question, consider an extension of the present model to a symmetric two-country two-industry world, in which each country is an exporter in one industry and an importer in the other. Notice that settling an $\mathrm{AD}$ cases can increase the level of protection only if it raises prices. Then, social welfare, consisting of consumer surplus and all firms' profits, must decline. Therefore, even if each country may have the incentive unilaterally to settle an $\mathrm{AD}$ duty for a VER, the simultaneous pursuit of such policy by both governments harms both countries. Further, since a higher level of import restriction decreases total industry profit, even if governments were more concerned with firm profit than consumer welfare, they would be better off agreeing to mutually ban VERs as a means to settling AD cases. Thus, the GATT/WTO ban on VERs can be regarded as a commitment device designed to avoid the prisoner's dilemma outcomes.

There may be even simpler explanation of the GATT ban on VERs in the light of our analysis. The importing country is generally worse off under a VER than under AD because there are no tariff revenues. If $\mathrm{AD}$ authorities could act independently to protect firms more than consumers, then it would be in the interest of the welfare-maximizing government to ban VERs. In this sense, too, the WTO ban can be regarded as a commitment device. ${ }^{6}$

Although we base our analysis on Cournot competition for simplicity sake, the mechanism driving our results is present in Bertrand competition as well. There, with a price

\footnotetext{
${ }^{6}$ We are grateful to a referee for suggesting that we explain the GATT ban on VERs in the light of our model, and providing this particular explanation.
} 
undertaking, investment by one firm still exerts a downward pressure on the export price, while with a VER it still relaxes the quota constraint facing the exporter. Therefore, foreign firms have more of an incentive to engage in FDI under a price undertaking than under a VER. Then our welfare implications remain valid. Further, since a VER yields a more collusive equilibrium outcome than a price undertaking as shown by Moore (2005), it makes all the more sense to ban VERs. 


\section{Appendix A}

In this appendix we prove Proposition 1 for the case of two foreign firms. Begin with a price undertaking, $\underline{p}$, which we assume is always binding. ${ }^{7}$ Further, for any impact on imports, $\underline{p}$ must exceed the free-trade price, a/4, which we also assume. Foreign Firm 1 maximizes profit

$$
\pi_{1}=\left(\mathrm{a}-\mathrm{x}_{1}-\mathrm{x}_{2}-\mathrm{x}_{\mathrm{h}}\right) \mathrm{x}_{1},
$$

subject to the constraint $\mathrm{p}=\mathrm{a}-\mathrm{x}_{1}-\mathrm{x}_{2}-\mathrm{x}_{\mathrm{h}} \geq \underline{\mathrm{p}}$. The best-response function is

$$
\mathrm{b}_{1}=\max \left\{\mathrm{a}-\mathrm{x}_{2}-\mathrm{x}_{\mathrm{h}}-\underline{\mathrm{p}},\left(\mathrm{a}-\mathrm{x}_{2}-\mathrm{x}_{\mathrm{h}}\right) / 2\right\}
$$

Interchanging subscripts yields the best-response function for foreign firm 2 . The home firm is not constrained by the price undertaking. Solving the three-best response functions simultaneously yields the following symmetric equilibrium export sales per foreign firm

$$
\mathrm{x}(\underline{\mathrm{p}})=(\mathrm{a}-2 \underline{\mathrm{p}}) / 2
$$

and $\mathrm{x}_{\mathrm{h}}(\mathrm{p})=\underline{\mathrm{p}}$ for the home firm. Each foreign firm makes the profit

$$
\pi(\underline{p})=\underline{p}(a-2 \underline{p}) / 2
$$

and the home firm makes

$$
\Pi(\underline{p})=\underline{p}^{2}
$$

We now compare an $\mathrm{AD}$ duty with a price undertaking that yield the same profit to the domestic firm. By comparing (3) with (A2), $\Pi(\mathrm{t})=\Pi(\underline{p})$ implies:

\footnotetext{
${ }^{7}$ For example, the European Commission closely monitors the price undertakings and imposes penalties to punish violators (Pauwels and Springael, 2002).
} 
(A3)

$$
\underline{p}=(a+2 t) / 4
$$

A comparison with (1) shows that the price is the same with an AD duty. It is easy to check that each firm's equilibrium outputs remain identical.

Consider now a VER of size $\mathrm{v}$ imposed on the volume of exports from the foreign country:

$$
\mathrm{x}_{1}+\mathrm{x}_{2} \leq \mathrm{v}
$$

Assume $\mathrm{v}<\mathrm{a} / 2$ to have any impact on imports, and that each foreign firm exports up to $\mathrm{v} / 2$. It is easy to check that the Nash equilibrium is

$$
\left(\mathrm{x}_{1}, \mathrm{x}_{2}, \mathrm{x}_{\mathrm{h}}\right)=(\mathrm{v} / 2, \mathrm{v} / 2,(\mathrm{a}-\mathrm{v}) / 2)
$$

In equilibrium, industry output is $(\mathrm{a}+\mathrm{v}) / 2$, and the price is

$$
\mathrm{p}=(\mathrm{a}-\mathrm{v}) / 2
$$

The profit to each foreign firm is

$$
\pi(\mathrm{v})=\mathrm{v}(\mathrm{a}-\mathrm{v}) / 2
$$

and that to the home firm is

$$
\text { (A5) } \quad \Pi(\mathrm{v})=(\mathrm{a}-\mathrm{v})^{2} / 4 \text {. }
$$

We now compare a VER with a price undertaking while keeping the home firm's profit constant. By (A2) and (A5), we have

$$
(\mathrm{a}-\mathrm{v}) / 2=\underline{\mathrm{p}}
$$


In equilibrium, each foreign firm exports $v / 2=(a-2 \underline{p}) / 2$, with the home firm producing $(a-$ v) $/ 2=\underline{p}$, as under the price undertaking $\underline{p}$. This proves the equivalence between a VER and a price undertaking.

\section{Appendix B}

This appendix contains results we used to draw Figures $2-4$.

Lemma 1 With AD

$\mathrm{A}:(\mathrm{E}, \mathrm{E})$ is the unique equilibrium if $\mathrm{k}>3 \mathrm{t}(2 \mathrm{a}-\mathrm{t}) / 16$.

B: (I, I) is the unique equilibrium if $\mathrm{k}<3 \mathrm{t}(2 \mathrm{a}-3 \mathrm{t}) / 16$.

C: Either (E, I) or (I, E) is the equilibrium if $3 \mathrm{t}(2 \mathrm{a}-3 \mathrm{t}) / 16<\mathrm{k}<3 \mathrm{t}(2 \mathrm{a}-\mathrm{t}) / 16$.

Proof: Result A is true if both these inequalities hold:

$$
\begin{aligned}
& (a-3 t)^{2} / 16>a^{2} / 16-k, \\
& (a-2 t)^{2} / 16>(a+t)^{2} / 16-k .
\end{aligned}
$$

The first is written

$$
16 k>3 t(2 a-3 t),
$$

and the second is written

$$
16 k>3 t(2 a-t)>3 t(2 a-3 t)
$$

Result A is immediate. Result B holds if inequalities (B1) and (B2) hold in reverse. If (B1) holds and (B2) holds in reverse, Result C obtains.

Lemma 2 With a price undertaking $\underline{\mathrm{p}} \in(\mathrm{a} / 4, \mathrm{a} / 3)$ corresponding to an $\mathrm{AD}$ duty $\mathrm{t} \in(0, \mathrm{a} / 6)$ 
A. (I, I) is the unique equilibrium if $\mathrm{k}<\mathrm{t}(\mathrm{a}-3 \mathrm{t}) / 4$.

B. $(E, E)$ is the unique equilibrium if $k>t(a+2 t) / 4$.

C. Either (E, I) or (I, E) is the equilibrium if $\mathrm{t}(\mathrm{a}-3 \mathrm{t}) / 4<\mathrm{k}<\mathrm{t}(\mathrm{a}+2 \mathrm{t}) / 4$.

Proof. Result A is true if both these inequalities hold:

$$
\begin{aligned}
& \mathrm{a}^{2} / 16-\mathrm{k}>(\mathrm{a}-3 \underline{\mathrm{p}}) \underline{p}, \\
& \underline{\mathrm{p}}^{2}-\mathrm{k}>\underline{\mathrm{p}}(\mathrm{a}-2 \underline{\mathrm{p}}) / 2 .
\end{aligned}
$$

Using the conversion formula, the first is written

$$
16 k<a^{2}-(a-6 t)(a+2 t)=4 t(a-3 t)
$$

and the second is written

$$
16 \mathrm{k}<4 \mathrm{t}(\mathrm{a}+2 \mathrm{t})
$$

Since $4 t(a-3 t)<4 t(a+2 t)$, we obtain Result A. Result B is true if inequalities (B3) and (B4) hold in reverse. If both (B3) fails and (B4) holds, Result C obtains.

Lemma 3: With a price undertaking $\underline{\mathrm{p}} \in(\mathrm{a} / 3,5 \mathrm{a} / 12)$ equivalent to the $\mathrm{AD}$ duty $\mathrm{t} \in(\mathrm{a} / 6, \mathrm{a} / 3)$
A: (I, I) is the unique equilibrium if $\mathrm{k}<\left(7 \mathrm{a}^{2}+36 \mathrm{t}^{2}\right) / 144$.
B: The equilibrium is either (I, I) or $(\mathrm{E}, \mathrm{E})$ if $\mathrm{k}>\left(7 \mathrm{a}^{2}+36 \mathrm{t}^{2}\right) / 144$.
C: (E, I) and (I, E) are never the equilibrium.

Proof: Result (A) is true if

$$
\mathrm{a}^{2} / 9-\mathrm{k}>\underline{\mathrm{p}}(\mathrm{a}-2 \underline{\mathrm{p}}) / 2 .
$$

Using the conversion formula, this is written 


$$
\mathrm{k}<\left(7 \mathrm{a}^{2}+36 \mathrm{t}^{2}\right) / 144
$$

If the inequality is reversed, (E, E) is also an equilibrium. Results (C) is obvious under the assumption that $\mathrm{k}<\mathrm{a}^{2} / 16$.

Lemma 4: With a VER $v \in(a / 4, a / 2)$ corresponding to $t \in(0, a / 4),(E, E)$ is the unique equilibrium.

Proof. The lemma is true if

$$
\mathrm{v}(\mathrm{a}-\mathrm{v}) / 2>\mathrm{a}^{2} / 16-\mathrm{k}
$$

Since $\mathrm{v}(\mathrm{a}-\mathrm{v}) / 2$ is bounded from below by $\mathrm{a}^{2} / 9$ for $\mathrm{a} / 2>\mathrm{v}>\mathrm{a} / 4$, this inequality always holds.

Lemma 5: With a VER $v \in(a / 6, a / 4)$ equivalent to the $A D$ duty $t \in(a / 4, a / 3)$

$\mathrm{A}:(\mathrm{E}, \mathrm{E})$ is the unique equilibrium if $\mathrm{k}>\left(44 \mathrm{t}^{2}+8 \mathrm{at}+7 \mathrm{a}^{2}\right) / 72$.

B: (I, I) is the unique equilibrium if $\mathrm{k}<\left(16 \mathrm{t}^{2}-\mathrm{a}^{2}\right) / 48$.

C: Either (E, E) or (I, I) is the equilibrium if

$$
\left(16 \mathrm{t}^{2}-\mathrm{a}^{2}\right) / 48<\mathrm{k}<\left(44 \mathrm{t}^{2}+8 \mathrm{at}+7 \mathrm{a}^{2}\right) / 72 .
$$

Proof. Result A is true if both these inequalities hold:

$$
\begin{aligned}
& v(a-v) / 2>(a-v)^{2} / 9-k \\
& a^{2} / 16-k<v(a-v) / 3 .
\end{aligned}
$$

Using the conversion formula, the first is written

$$
\mathrm{k}>\left(44 \mathrm{t}^{2}+8 \mathrm{at}-7 \mathrm{a}^{2}\right) / 72
$$


and the second is written

$$
\mathrm{k}>\left(16 \mathrm{t}^{2}-\mathrm{a}^{2}\right) / 48 \text {. }
$$

Result A follows because $\left(44 \mathrm{t}^{2}+8 \mathrm{at}-7 \mathrm{a}^{2}\right) / 72<\left(16 \mathrm{t}^{2}-\mathrm{a}^{2}\right) / 48$ for $\mathrm{a} / 4<\mathrm{t}<\mathrm{a} / 3$. Result $\mathrm{B}$ is true if both inequalities hold in reverse. Result $\mathrm{C}$ is true if both these inequalities hold:

$$
\begin{aligned}
& \mathrm{v}(\mathrm{a}-\mathrm{v}) / 2>(\mathrm{a}-\mathrm{v})^{2} / 9-\mathrm{k} \\
& \mathrm{a}^{2} / 16-\mathrm{k}>\mathrm{v}(\mathrm{a}-\mathrm{v}) / 3 .
\end{aligned}
$$

\section{Appendix C}

We compute home country welfare with a price undertaking that leads to the equilibrium (E, E) in Case I. Calculations show that the equilibrium consumer surplus is $(\mathrm{a}-\underline{\mathrm{p}})^{2} / 2$, and hence the home welfare is

$$
\mathrm{W}_{\mathrm{EE}}(\underline{\mathrm{p}})=(\mathrm{a}-\underline{\mathrm{p}})^{2} / 2+\underline{\mathrm{p}}^{2},
$$

where $\underline{p} \geq a / 4 . W_{E E}(\underline{p})$ is decreasing for $\underline{p}<a / 3$ and increasing for $\underline{p}>a / 3$. Welfare reaches its maximum value of $3 a^{2} / 8$ at $\underline{p}=a / 2$, at which imports vanish. Given the equivalence, home country welfare is also decreasing in $\mathrm{t}<\mathrm{a} / 6$. 


\section{References}

Belderbos, R., Vandenbussche, H., and Veugelers, R., 2004. Antidumping duties, undertakings, and foreign direct investment in the EU. European Economic Review 48, 429-453.

Blonigen, B.A., and Ohno, Y., 1998, Endogenous protection, foreign investment and protection building trade, Journal of International Economics 46, 206-227.

Blonigen, B.A., Tomlin, K., Wilson, W. W., 2004. Tariff-jumping FDI and domestic firms' profits. Canadian Journal of Economics, 37, 656-677.

Hwang, H., and Mai, C.C., 1988. On the equivalence of tariffs and quotas under duopoly: a conjectural variation approach, Journal of International Economics 24, 373-380

Horstmann, I. J., and Markusen, J. R., 1987. Strategic investments and the development of multinationals, International Economic Review 28, 109-121.

Ishikawa, J., 1994, Ranking alternative trade-restricting policies under international duopoly, Japan and the World Economy 6, 157-169.

Ishikawa, J., 1998. Who benefits from voluntary export restraints? Review of International Economics 6, 129-141.

Krishna, K., 1989. Trade restrictions as facilitating practices, Journal of International Economics 26, 251-270.

Messerlin, P., 1989. The EC antidumping regulations: a first economic appraisal, 1980-1985. Weltwirtschaftliches Archiv, 125, 563-587.

Miyagiwa, K., and Y. Ohno, 1998, Planting disinformation through voluntary export restraints, Pacific Economic Review 3, 91-102. 
Moore, M., O., 2005, VERs and price undertakings under the WTO, Review of International Economics 13, 298-310.

Motta, M., 1992, Multinational firms and the tariff jumping argument: a game theoretical analysis with some unconventional conclusions. European Economic Review 36, 15571571.

Pauwels, W., and Springael, L., 2002. The welfare effect of a European anti-dumping duty and price-undertaking policy. Atlantic Economic Journal 30, 121-135

Prusa, T. J., 1992. Why are so many antidumping petitions withdrawn? Journal of International Economics 33, 1-20.

Prusa, T. J., 2001. On the spread and impact of anti-dumping. Canadian Journal of Economics $34,591-611$.

Vandenbussche, H., and Wauthy, X., 2001. Inflicting injury through product quality: how European antidumping policy disadvantages European producers. European Journal of Political Economy 17, 101-116. 


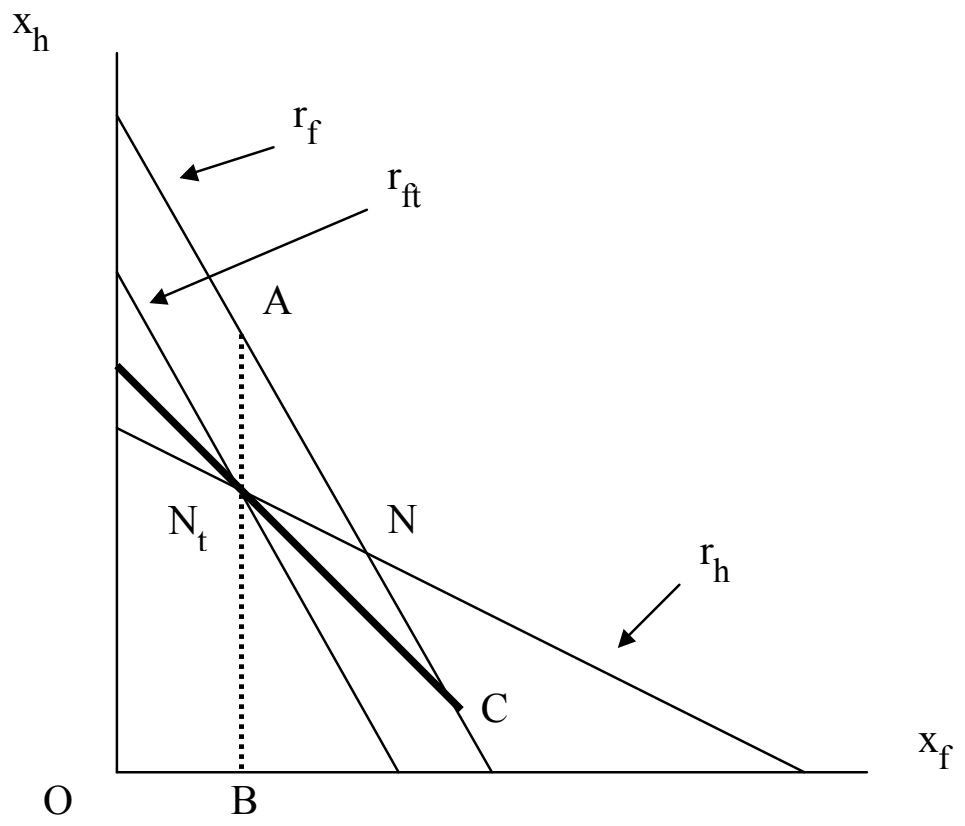

Figure 1: The equilibrium outcomes with only one foreign firm 


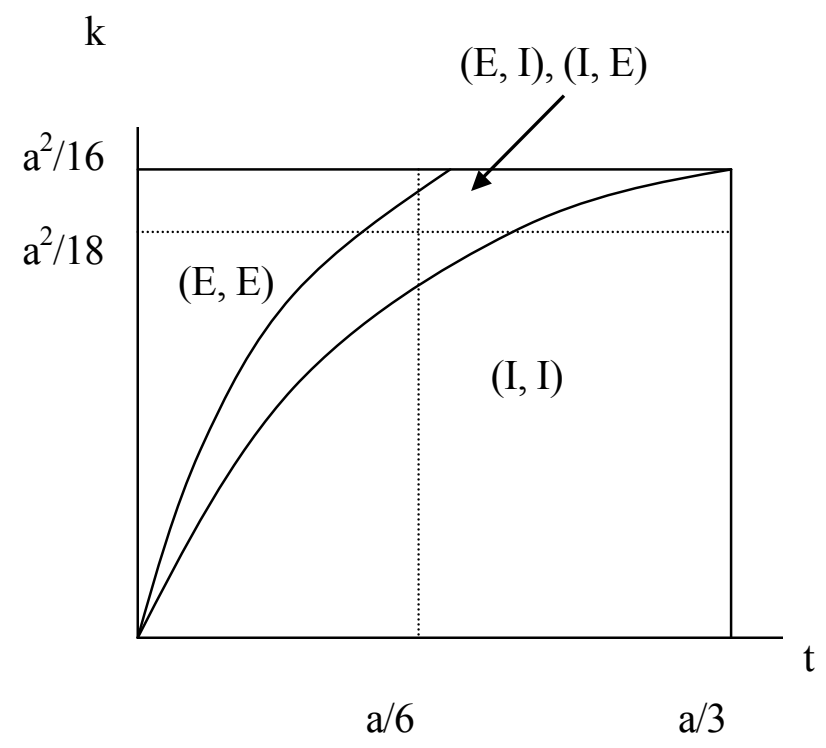

Figure 2: Equilibrium outcomes under $\mathrm{AD}$ 


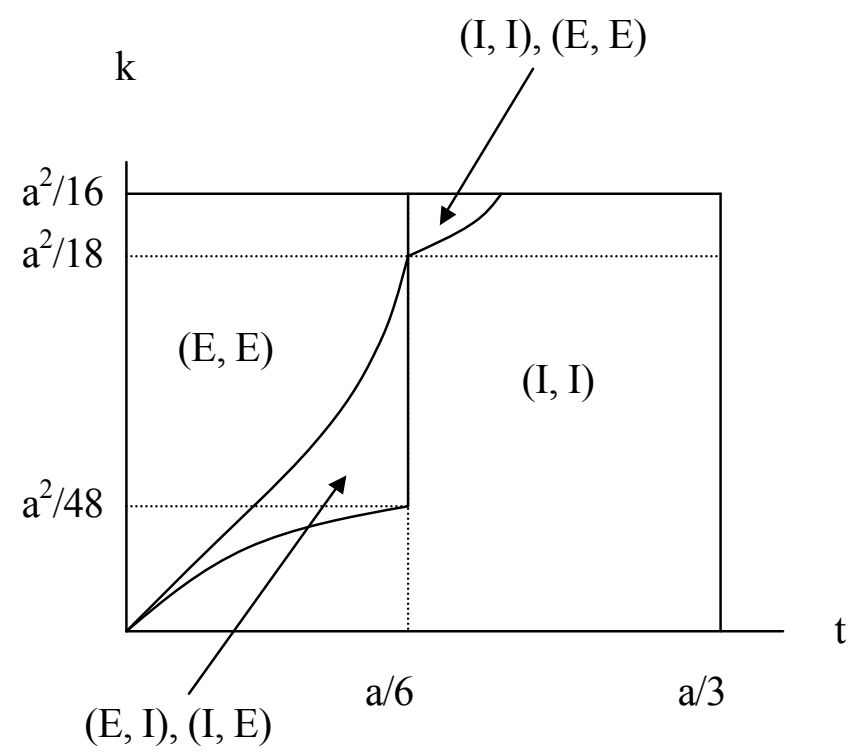

Figure 3: Equilibrium outcomes under price undertakings 


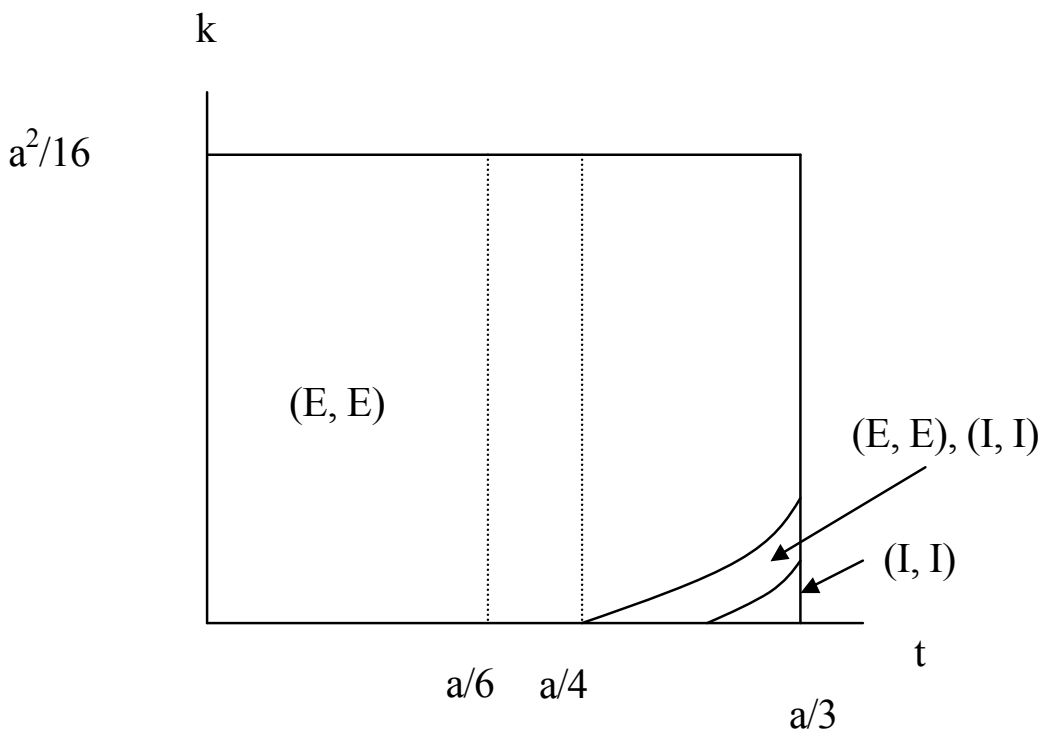

Figure 4: Equilibrium outcomes under VERs 